\title{
Maturity Models and Sustainable Indicators-A New Relationship
}

\author{
Márcia Cristina Machado*(D) and Tereza Cristina Melo de Brito Carvalho $(D$ \\ Escola Politécnica, Universidade de São Paulo/LASSU, Butanta 05508-060, SP, Brazil; terezacarvalho@usp.br \\ * Correspondence: macrismachado@usp.br; Tel.: +55-119-810-56774
}

\begin{abstract}
check for updates

Citation: Machado, M.C.; Carvalho, T.C.M.B. Maturity Models and Sustainable Indicators-A New Relationship. Sustainability 2021, 13, 13247. https://doi.org/10.3390/ su132313247
\end{abstract}

Academic Editors: Byung Il Park and Simon Shufeng Xiao

Received: 12 October 2021

Accepted: 25 November 2021

Published: 30 November 2021

Publisher's Note: MDPI stays neutral with regard to jurisdictional claims in published maps and institutional affiliations.

Copyright: (c) 2021 by the authors. Licensee MDPI, Basel, Switzerland. This article is an open access article distributed under the terms and conditions of the Creative Commons Attribution (CC BY) license (https:/ / creativecommons.org/licenses/by/ $4.0 /)$.
Abstract: This study aims to investigate the relationship between maturity models adopted by information technology companies and the sustainability indicators that are currently considered decision-making factors for investors and customers. The research is based on previous studies, Control Objectives for Information and Related Technology (COBIT), and Global Reporting Initiative (GRI) standards, and indicators of the Sustainable Development Goals (SDG) defined in 2015 by the United Nations. As a result of the intersection between the GRI and SDG indicators with COBIT requirements, a set of 50 indicators covering four dimensions of sustainability was identified. In the environmental dimension, 11 indicators were identified, in the economic dimension six indicators, in social dimension 14 indicators, and, at last, in the governance dimension, there were 19 convergent indicators between COBIT and GRI. This set of 50 proposed indicators was validated by analyzing the content of the sustainability reports available on the websites of information technology companies, making it possible to relate the sustainable practices and strategies adopted by such companies with the indicators suggested in this study. Furthermore, we identified that the SDGs are incorporated into the strategic objectives of seven of the nine companies analyzed.

Keywords: governance indicators; information technology; maturity models; SME; software; sustainability indicators

\section{Introduction}

In a competitive and highly connected world, technology companies play a key role as providers of solutions and services [1]. As a result of the restrictions imposed by the pandemic, these companies have seen their economic value increase, almost in proportion to the pressure from stakeholders and society for greater transparency in data management, ethics, and socioenvironmental responsibility [2].

To face these pressures, the adoption of strategic and operational management models aligned with sustainability, and the establishment of measurable goals through indicators that show the materiality of the operations, have become indispensable tools [3].

Indicators are generally implemented as a measure to assess a company in relation to the quality of its services and/or products, operational or financial performance, customer, employee, or stakeholder satisfaction, and are also used to assess the level of sustainability of a company, city, or country [4]. In the field of sustainability, several indicators have been proposed, but, according to [5], the set of variables used to compose these indicators, such as the Environmental Sustainability Index (ESI), Environmental Performance Index (EPI), Adjusted Net Economy (ANS), and the Ecological Footprint, present conflicting or contradictory results.

In view of this scenario, Agenda 21 was proposed, which reinforced the need to establish indicators that allow the sustainable development of the millennium to be assessed, giving rise to the Sustainable Development Goals (SDGs) which are presented as relevant, measurable, easily communicated, accessible indicators, and with a focus on results [6]. However, the metrics proposed in Agenda 21 do not always meet corporate objectives, generating the need for a new set of indicators that assess sustainability in companies. 
In the software engineering environment, the steps to determine the metrics can be oriented towards product evaluation - product inspection and quality control; processevolution of the life cycle and management of activities at the operational level and system management-guarantee of product quality and technical information [7-9]. Another mechanism adopted is the maturity model that supports the development and control of processes, the optimization of established procedures, and also an improvement in product quality and the management of related activities, promoting the best use of available resources [10].

The optimization of resources can also be measured through annual or biennial sustainability and/or social responsibility reports, in which companies inform the results of their performance indicators and describe voluntary or mandatory actions to improve environmental, economic, and social performance operations [11]. This information, which started with the Corporate Social Responsibility (CSR) approach, has gained new outlines and has recently come to be known as Environmental Social and Governance (ESG) criteria, making social and environmental issues an indispensable part of companies' strategy $[2,12]$.

One of the most adopted models to develop the Sustainability Report in companies is the Global Reporting Initiative (GRI), which uses inventory processes as a basis for data collection. This standardized model provides an overview of an organization's sustainable practices for investors, customers, employees, and stakeholders [11,13].

In software and information and communication technology (ICT) companies, the preparation and dissemination of sustainability reports has become a practice adopted by large companies or global organizations; however, among Brazilian micro and small software companies, which represent $95.5 \%$ of a total of 5924 companies in the sector, the dissemination of sustainable actions and practices has not yet occurred due to difficulties in implementing and measuring sustainability indicators [14,15].

Thus, this study has a main objective to develop a set of sustainable indicators that can be adopted by micro and small software companies, based on the connection between the sustainability indicators proposed by SGD and GRI, and the requirements of the COBIT maturity model. This set of indicators can help micro and small companies to assess their level of adherence to sustainability and identify points that need improvement.

After this introduction, Section 2 presents the theoretical framework that supports this study, which includes sustainable indicators, GRI, SDG, COBIT, and IT governance. Section 3 describes the research method carried out in this study. In Section 4, the analysis of sustainability indicators related to the requirements of the maturity model is presented, and the results obtained with this relationship are presented, which were based on the description of the application, of each item, of the analyzed requirements and indicators. Finally, Section 5 brings the final discussions and conclusions.

\section{Materials and Methods}

This study uses exploratory research as a method. For this purpose, research was carried out in the academic databases of Web of Science, IEEE, Scopus, and Google Scholar, in order to identify related works that address the theme of sustainability, COBIT maturity models, sustainable indicators in ICT, and IT governance, to compose a reliable theoretical basis, eliminating the subjectivity of researchers and providing subsidies for the elaboration of the proposed theoretical model. The updated versions of COBIT 2019, GRI-GSSB, and the SDGs and their targets were also analyzed $[16,17]$.

Data collection performed for this study relied on electronic searches on the websites of the largest information technology companies that publish sustainability reports and adopt maturity models as one of the management and assessment tools for their operations. To analyze this dataset, the summative content analysis method was applied, which involves counting and comparisons, using the content, followed by the interpretation of the context related to the reporting patterns used [18]. 


\section{Theorical Framework}

This section aims to present the literature reviews and research that will support the proposed study, the structures used in the dissemination of sustainable practices, the goals to achieve the objectives of sustainable development, and the models of corporate maturity.

\subsection{Indicators}

The need to establish sustainable indicators emerged when Agenda 21 was drawn up, as it became imperative to investigate and outline the measures adopted by several countries to achieve sustainability and the well-being of the population; therefore, the use of relevant and globally applicable indicators proved to be fundamental for a global sustainability assessment [19].

An indicator can be understood as a "parameter that points out, provides information about, or describes the state of a phenomenon with relevance and importance for performance objectives". Metrics means "a measurable amount to track one or more indicators". In order to assess sustainability in the production process to verify material consumption, energy use, waste generation, and related manufacturing processes, indicators are created, and sustainable targets are established [20].

The sustainability indicators originally proposed by [21] were implemented in the life cycle analysis and were organized into three criteria: usability, relevance, and robustness of the related method. These indicators were grouped into hierarchical levels, starting with level 1 (sustainability footprint), level 2 (best practices), and level 3 (comprehensive assessment); building a set of indicators for assessing the sustainability of the product's life cycle [22] proposed 16 indicators to assess the sustainability of manufacturing companies considering four dimensions - environmental, economic, social, and governance.

In the case of ICT infrastructure, energy consumption in data centers is one of the biggest costs of its operation [17]. For this reason, the establishment of goals for the management of consumption and acquisition of energy from renewable sources, the use of energy-efficient equipment, and the adoption of intelligent cooling systems led to the creation of the Silicon Valley Commission (CA-USA), which established goals for the control and management of these resources in data centers [23].

Likewise, ecological and sustainable software is designed, from the beginning, to improve the use of energy and other natural resources, whether at the stage of development, implementation, use and/or storage, promoting the analysis of the life cycle process of the software $[24,25]$.

\subsection{Sustainability Report (GRI)}

The Global Sustainability Standards Board (GSSB) is the agent responsible for preparing the set of standards with which organizations provide information on environmental, economic, and social impacts, positive or negative, considering the goals of sustainable operation and sustainable development programs. Being a globally accepted and recognized model, sustainability reports generated using the Global Reporting Initiative (GRI) set of standards allow you to compare business results, highlight transparency, promote accountability for organizations, and allow external and internal stakeholders to make decisions about investments, relationships, or business partnerships [26].

In sustainability reports based on GRI standards, materiality (all "significant impacts" arising from the activities carried out by the company that might concern an expert's community or that have been detected by causing any impact or life cycle assessments, requiring management and/or active involvement of the organization, should be reported) is the determining principle for defining which items are strategically relevant and, therefore, be part of them. It should also be noted that materiality assessments must meet the expectations expressed in the international standards and agreements established by the company [12]. In this sense, it is observed that the evolution of materiality for environmental, social, and governance (ESG) data appears as a response to investors' expectations 
so that these data can be compiled, enabling financial risk assessments, in addition to materiality $[27,28]$.

When preparing the report according to the GRI standards, companies must choose the main (core) version that contains the main elements, focusing on the process of identifying aspects (those that reflect economic, social, and environmental effects) or a comprehensive version, which, in addition to meeting the items in the essential version, adds information on strategy, analysis, governance, ethics, and integrity, in addition to reporting broadly the indicators regarding the material aspects identified [27].

\subsection{Sustainable Development Goals (SDG)}

The Sustainable Development Goals (SDGs) comprise the 2030 Agenda established by the United Nations Summit in September 2015, in New York (USA) with the eradication of poverty in all its forms, gender equity, aggregating them in the three dimensions of sustainability as the main focus [29]. The 2030 Agenda presents these guidelines through 17 objectives and 169 goals that address social, environmental, economic, and institutional issues, constituting a set of indicators that make it possible to monitor progress and ensure everyone's engagement [30].

These objectives were designed to complete the Millennium Development Goals, proposed in Agenda 21, and seek to guide the actions of governments, organizations, and civil society in areas critical to humanity and the planet, involving people, the planet, prosperity, peace, and the global partnership for sustainable development [6].

The 17 objectives for sustainable development proposed by the UN Commission are as follows:

"1-End poverty in all its forms everywhere. 2-Zero Hunger. End hungers achieve food security and improved nutrition and promote sustainable agriculture. 3-Ensure a healthy life and promote well-being for all at all ages. 4-Ensure inclusive and equitable education and promote lifelong learning opportunities for all. 5-Achieve gender equality and empower all women and girls. 6-Ensure availability and sustainable management of water and sanitation for all. 7-Ensure access to affordable, reliable, sustainable, and modern energy for all. 8-Promote sustained, inclusive, and sustainable economic growth, full and productive employment, and decent work for all, 9-Build resilient infrastructure, promote sustainable and inclusive industrialization and foster innovation. 10-Reduce inequality within and among countries. 11-Make cities and human settlements inclusive, safe, resilient, and sustainable. 12-Ensure sustainable consumption and production patterns. 13-Take urgent action to combat climate change and its impacts. 14-Conserve and sustainably use the oceans, seas, and marine resources for sustainable development. 15-Protect, restore, and promote sustainable use of terrestrial ecosystems, sustainably manage forests, combat desertification, and halt and reverse land degradation and halt biodiversity loss. 16-Promote peaceful and inclusive societies for sustainable development, provide access to justice for all and build effective, accountable, and inclusive institutions at all levels. 17-Strengthen the means of implementation and revitalize the global partnership for sustainable development." (Obtained in 18 August 2021 from https:/ / un.org/sustainabledevelopment/).

The adoption of the Sustainable Development Goals by the countries of South America is based on the most emerging needs, generally related to zero hunger, housing and sanitation, and emission control of greenhouse gases (GHG) arising mainly from deforestation. These countries face great difficulties in following all the objectives determined in Agenda 2030, since this Agenda considers that governments are the majority in decisions and must adapt their internal development goals to the main objectives proposed in Agenda 2030 [31].

On the other hand, Latin American companies have shown an interest in the management and disclosure of sustainability actions, especially as there is a strong tendency among investors to allocate resources to companies that disclose ESG reports [12]. It was 
also observed that companies with a diversified board of directors and with CEOs whose goal is sustainability, the disclosure of impact data related to ESG will be made public [12].

\subsection{Maturity Models and Information Technology Governance}

Among the maturity models adopted by software companies, Capability Maturity Model Integration (CMMI), Control Objectives for Information and Related Technology (COBIT), and Information Technology Infrastructure Library (ITIL) stand out [32]. They concentrate the largest adhesion of companies due to their practical application in management, control, and guidance of best practices in the software and information technology sector [33]. In publicly traded companies, since the establishment of the Sarbanes-Oxley (SOX) law, the disclosure of internal controls over activities developed internally or externally in the information technology area and the security processes involving company data have become part of the corporate governance, with COBIT as the most used model [34].

\section{- $\quad$ COBIT Structure}

COBIT is a model for the governance and management of a company's information technology. It is implemented in organizations as a tool to measure the achievement of the objectives of improving the quality of the process, as well as standardizing the activities carried out and improving governance initiatives.

The structure of COBIT 2019 has two dimensions, one for governance and another for management, and 40 management objectives distributed in five domains, integrating design factors and focus areas as indicated in the COBIT guidelines, created by the Association of Control and Audit Systems Information-ISACA. In the most recent version, it also aligns the maturity levels from 0 to 5 with the CMMI, enabling the ability to execute all processes successfully and promoting the ongoing progress of IT management and governance [35].

COBIT is considered one of the most used models to manage, control, and guarantee the best practices of information technology (IT), and incorporates the standards of ISO/IEC20000, ISO/IEC 27000, and ISO/IEC 38500 and alignment with models such as ITIL and CMMI, in addition to being an important determining factor for the disclosure of information on IT governance in annual reports [36].

\section{- $\quad$ IT Governance}

IT governance is a set of mechanisms that control the balance of activities and the appropriate use of resources, by which leaders perform the functions of representation, regulation, service provision, and formulation of public policies, integrating the various IT actors $[37,38]$.

Corporate governance can be described as a set of activities that include authority, control, accountability, definition of functions, and responsibilities aiming at the transparency of operations, and it requires top management to transparently disclose information and results of operations to the board, shareholders, stakeholders, and employees [39-41].

IT governance (ITG) can be defined as the organizational capacity exercised by the board of directors, senior managers, and IT managers in the elaboration of strategies and controls for information technology activities, so that they remain aligned with the business strategy $[37,42]$.

The mechanisms that make up IT governance can contribute to increased organizational performance and efficiency, as they help to reduce infrastructure costs through the appropriate use of resources [39]. When the organization includes people management resources for managing IT resources (automate, computerize, transform, and infrastructure), it reveals the possibility of developing these resources with a sustainable bias $[43,44]$.

\section{Results}

In this section, we present the results of the comparative analyses between the SDG indicators and GRI-GSSB items with the requirements of COBIT 2019, considering that the objective of this study is to develop a set of indicators that enable the sustainability data records of micro and small software companies. The analyses of the sustainability 
and/or social responsibility reports prepared and made available by nine global technology companies are presented, aiming to validate the adherence of the proposed set of indicators with the indicators used by these companies. This validation was carried out because micro and small companies do not yet practice the dissemination of their sustainable actions.

\subsection{Convergence among Sustainability Indicator Standards (GRI, SDG, COBIT)}

Taking, as a guideline, the 17 SDGs and the 169 related goals, a comparative content analysis was carried out to outline similarities between the SDG and the GRI-GSSB 141 report items, prioritizing the indicators used in the software industry. After the end of this comparison, the 232 requirements of COBIT 2019 were analyzed to identify the adherence of these objectives to the ODS indicators and the GRI-GSSB items, generating a set of 50 indicators and/or items.

These 50 identified indicators (see Table 1) have similarities and/or convergence with each other, and are grouped within the four dimensions of sustainability, as shown below.

Table 1. Convergence among GRI and SDG and COBIT2019 indicators.

\begin{tabular}{|c|c|c|c|}
\hline $\begin{array}{l}\text { Dimension } \\
\text { Indicator }\end{array}$ & $\begin{array}{l}\text { Global Reporting } \\
\text { Initiative (GSSB) }\end{array}$ & $\begin{array}{l}\text { Sustainable Development Goals } \\
\text { (Targets Associated) }\end{array}$ & $\begin{array}{l}\text { COBIT } 2019 \text { (Governance and } \\
\text { Management Objectives) }\end{array}$ \\
\hline GVN1 & $\begin{array}{l}102-11=>\text { Precautionary } \\
\text { Principle or approach }\end{array}$ & & $\begin{array}{l}\text { EDM02.01 Establish the target } \\
\text { investment mix; } \\
\text { MEA02.02 Review effectiveness of } \\
\text { business process controls. }\end{array}$ \\
\hline GVN2 & $\begin{array}{l}\text { 102-15 => Key impacts, risks, } \\
\text { and opportunities }\end{array}$ & & $\begin{array}{l}\text { EDM03.01 Evaluate risk management; } \\
\text { EDM03.02 Direct risk management. }\end{array}$ \\
\hline GVN3 & $\begin{array}{c}102-16=>\text { Values, principles, } \\
\text { standards, and norms of } \\
\text { behavior }\end{array}$ & $\begin{array}{l}\text { 16.3 Promote the rule of law at the } \\
\text { national and international levels and } \\
\text { ensure equal access to justice for all. }\end{array}$ & $\begin{array}{l}\text { MEA04.01 Ensure that assurance } \\
\text { providers are independent and qualified. }\end{array}$ \\
\hline GVN4 & $\begin{array}{c}102-17=>\text { Mechanisms for } \\
\text { advice and concerns about } \\
\text { ethics }\end{array}$ & 16.3 & $\begin{array}{l}\text { MEA04.01 Ensure that assurance } \\
\text { providers are independent and qualified. }\end{array}$ \\
\hline GVN5 & $\begin{aligned} 102-18 & =>\text { Governance } \\
& \text { structure }\end{aligned}$ & & $\begin{array}{l}\text { APO01.01 Design the management } \\
\text { system for enterprise I\&T; } \\
\text { APO01.04 Define and implement the } \\
\text { organizational structures; } \\
\text { EDM01.02 Direct the governance system. }\end{array}$ \\
\hline GVN6 & $\begin{array}{l}102-19=>\text { Delegating } \\
\text { authority }\end{array}$ & & $\begin{array}{l}\text { APO01.01 Design the management } \\
\text { system for enterprise I\&T; } \\
\text { APO01.05 Establish roles and } \\
\text { responsibilities; } \\
\text { EDM01.01 Evaluate the governance } \\
\text { system. }\end{array}$ \\
\hline GVN7 & $\begin{array}{c}\text { 102-21 => Consulting } \\
\text { stakeholders on economic, } \\
\text { environmental, and social } \\
\text { topics }\end{array}$ & $\begin{array}{l}\text { 16.7 Ensure responsive, inclusive, } \\
\text { participatory, and representative } \\
\text { decision-making at all levels }\end{array}$ & $\begin{array}{c}\text { APO02.05 Define the strategic plan and } \\
\text { road map; } \\
\text { APO02.06 Communicate the I\&T strategy } \\
\text { and direction; } \\
\text { BAI01.03 Manage stakeholder } \\
\text { engagement; } \\
\text { EDM01.01 Evaluate the governance } \\
\text { system. }\end{array}$ \\
\hline GVN8 & $\begin{array}{c}102-26=>\text { Role of highest } \\
\text { governance body in setting } \\
\text { purpose, values, and strategy }\end{array}$ & & $\begin{array}{l}\text { APO01.09 Define and communicate } \\
\text { policies and procedures. }\end{array}$ \\
\hline GVN9 & $\begin{array}{l}102-28=>\text { Evaluating the } \\
\text { highest governance body's } \\
\text { performance }\end{array}$ & & $\begin{array}{l}\text { EDM01.03 Monitor the governance } \\
\text { system. }\end{array}$ \\
\hline
\end{tabular}


Table 1. Cont.

\begin{tabular}{|c|c|c|c|}
\hline $\begin{array}{l}\text { Dimension } \\
\text { Indicator }\end{array}$ & $\begin{array}{l}\text { Global Reporting } \\
\text { Initiative (GSSB) }\end{array}$ & $\begin{array}{l}\text { Sustainable Development Goals } \\
\text { (Targets Associated) }\end{array}$ & $\begin{array}{l}\text { COBIT } 2019 \text { (Governance and } \\
\text { Management Objectives) }\end{array}$ \\
\hline GVN10 & $\begin{array}{c}\text { 102-29 => Identifying and } \\
\text { managing economic, } \\
\text { environmental, and social } \\
\text { impacts }\end{array}$ & 16.7 & $\begin{array}{l}\text { EDM02.01 Establish the target } \\
\text { investment mix. }\end{array}$ \\
\hline GVN11 & $\begin{array}{c}102-30=>\text { Effectiveness of risk } \\
\text { management processes }\end{array}$ & & $\begin{array}{c}\text { APO01.11 Manage continual } \\
\text { improvement of the I\&T management } \\
\text { system; } \\
\text { APO12.02 Analyze risk; } \\
\text { EDM01.03 Monitor the governance } \\
\text { system; } \\
\text { EDM03.02 Direct risk management. }\end{array}$ \\
\hline GVN12 & $\begin{array}{c}102-31=>\text { Review of } \\
\text { economic, environmental, and } \\
\text { social topics }\end{array}$ & & $\begin{array}{l}\text { EDM02.03 Direct value optimization; } \\
\text { EDM03.03 Monitor risk management; } \\
\text { MEA03.01 Identify external compliance } \\
\text { requirements. }\end{array}$ \\
\hline GVN13 & $\begin{array}{c}102-40=>\text { List of stakeholder } \\
\text { groups }\end{array}$ & & $\begin{array}{l}\text { MEA01.01 Establish a monitoring } \\
\text { approach. }\end{array}$ \\
\hline GVN14 & $\begin{array}{l}\text { 102-42 => Identifying and } \\
\text { selecting stakeholders }\end{array}$ & & $\begin{array}{l}\text { MEA01.01 Establish a monitoring } \\
\text { approach. }\end{array}$ \\
\hline GVN15 & $\begin{array}{l}102-43=>\text { Approach to } \\
\text { stakeholder engagement }\end{array}$ & & $\begin{array}{c}\text { BAI11.03 Manage stakeholder } \\
\text { engagement; } \\
\text { MEA01.02 Set performance and } \\
\text { conformance targets; } \\
\text { MEA03.01 Identify external compliance } \\
\text { requirements; } \\
\text { EDM05.01 Evaluate stakeholder } \\
\text { engagement and reporting requirements. }\end{array}$ \\
\hline GVN16 & $\begin{array}{l}\text { 102-44 => Key topics and } \\
\text { concerns raised }\end{array}$ & & $\begin{array}{l}\text { EDM05.03 Monitor stakeholder } \\
\text { engagement. }\end{array}$ \\
\hline GVN17 & $\begin{array}{l}\text { 103-1 => Explanation of the } \\
\text { material topic and its } \\
\text { Boundary }\end{array}$ & & $\begin{array}{l}\text { APO01.02 Communicate management } \\
\text { objectives, direction and decisions made; } \\
\text { EDM04.02 Direct resource management. }\end{array}$ \\
\hline GVN18 & $\begin{array}{l}103-2=>\text { The management } \\
\text { approach and its components }\end{array}$ & & $\begin{array}{l}\text { EDM04.03 Monitor resource } \\
\text { management. }\end{array}$ \\
\hline GVN19 & $\begin{array}{l}\text { 103-3 => Evaluation of the } \\
\text { management approach }\end{array}$ & & $\begin{array}{c}\text { APO01.03 Implement management } \\
\text { processes (to support the achievement of } \\
\text { governance and management objectives); } \\
\text { EDM02.02 Evaluate value optimization; } \\
\text { EDM04.01 Evaluate resource } \\
\text { management. }\end{array}$ \\
\hline
\end{tabular}


Table 1. Cont.

\begin{tabular}{|c|c|c|c|}
\hline $\begin{array}{l}\text { Dimension } \\
\text { Indicator }\end{array}$ & $\begin{array}{l}\text { Global Reporting } \\
\text { Initiative (GSSB) }\end{array}$ & $\begin{array}{l}\text { Sustainable Development Goals } \\
\text { (Targets Associated) }\end{array}$ & $\begin{array}{l}\text { COBIT } 2019 \text { (Governance and } \\
\text { Management Objectives) }\end{array}$ \\
\hline ECN1 & $\begin{array}{l}201-1=>\text { Direct economic } \\
\text { value generated and } \\
\text { distributed }\end{array}$ & $\begin{array}{l}\text { 1.2 By 2030, reduce at least by half the } \\
\text { proportion of men, women, and children of all } \\
\text { ages living in poverty in all its dimensions } \\
\text { according to national definitions. } \\
\text { 8.1 Sustain per capita economic growth in } \\
\text { accordance with national circumstances and, in } \\
\text { particular, at least } 7 \text { per cent gross domestic } \\
\text { product growth per annum in the } \\
\text { least-developed countries. 8.2 Achieve higher } \\
\text { levels of economic productivity through } \\
\text { diversification, technological upgrading, and } \\
\text { innovation, including through a focus on } \\
\text { high-value added and labor-intensive sectors. } \\
\text { 9.1 Develop quality, reliable, sustainable, and } \\
\text { resilient infrastructure, including regional and } \\
\text { transborder infrastructure, to support economic } \\
\text { development and human well-being, with a } \\
\text { focus on affordable and equitable access for all. } \\
\text { 9.4 By 2030, upgrade infrastructure and retrofit } \\
\text { industries to make them sustainable, with } \\
\text { increased resource-use efficiency and greater } \\
\text { adoption of clean and environmentally sound } \\
\text { technologies and industrial processes, with all } \\
\text { countries taking action in accordance with their } \\
\text { respective capabilities. 9.5 Enhance scientific } \\
\text { research, upgrade the technological capabilities } \\
\text { of industrial sectors in all countries, in particular } \\
\text { developing countries, including, by } 2030 \text {, } \\
\text { encouraging innovation and substantially } \\
\text { increasing the number of research and } \\
\text { development workers per } 1 \text { million people and } \\
\text { public and private research and development } \\
\text { spending. }\end{array}$ & $\begin{array}{l}\text { APO06.01 Manage finance and } \\
\text { accounting. }\end{array}$ \\
\hline ECN2 & $\begin{array}{l}\text { 201-2 => Financial } \\
\text { implications and other } \\
\text { risks and opportunities } \\
\text { due to climate change }\end{array}$ & $\begin{array}{l}\text { 13.1 Strengthen resilience and adaptive capacity } \\
\text { to climate-related hazards and natural disasters } \\
\text { in all countries. }\end{array}$ & $\begin{array}{l}\text { DSS01.04 Manage the environment; } \\
\text { EDM03.01 Evaluate risk } \\
\text { management. }\end{array}$ \\
\hline ECN3 & $\begin{array}{c}\text { 203-1 => Infrastructure } \\
\text { investments and services } \\
\text { supported }\end{array}$ & $\begin{array}{l}\text { 5.4 Recognize and value unpaid care and } \\
\text { domestic work through the provision of public } \\
\text { services, infrastructure. and social protection } \\
\text { policies and the promotion of shared } \\
\text { responsibility within the household and the } \\
\text { family as nationally appropriate. 9.1; } 9.4 ; \mathbf{1 1 . 2} \text { By } \\
\text { 2030, provide access to safe, affordable, } \\
\text { accessible, and sustainable transport systems for } \\
\text { all, improving road safety, notably by expanding } \\
\text { public transport, with special attention paid to } \\
\text { the needs of those in vulnerable situations, } \\
\text { women, children, persons with disabilities, and } \\
\text { older persons. }\end{array}$ & $\begin{array}{l}\text { APO04.02 Maintain an understanding } \\
\text { of the enterprise environment. } \\
\text { EDM02.02 Evaluate value } \\
\text { optimization. } \\
\text { EDM02.04 Monitor value } \\
\text { optimization. }\end{array}$ \\
\hline
\end{tabular}


Table 1. Cont.

\begin{tabular}{|c|c|c|}
\hline $\begin{array}{l}\text { Dimension } \\
\text { Indicator }\end{array}$ & $\begin{array}{l}\text { Global Reporting } \\
\text { Initiative (GSSB) }\end{array}$ & $\begin{array}{l}\text { Sustainable Development Goals } \\
\text { (Targets Associated) }\end{array}$ \\
\hline ECN4 & $\begin{array}{l}\text { 203-2 => Significant } \\
\text { indirect economic impacts }\end{array}$ & $\begin{array}{c}\text { 1.2; } 1.4 \text { By 2030, ensure that all men and women, } \\
\text { in particular the poor and the vulnerable, have } \\
\text { equal rights to economic resources, as well as } \\
\text { access to basic services, ownership, and control } \\
\text { over land and other forms of property, } \\
\text { inheritance, natural resources, appropriate new } \\
\text { technology, and financial services, including } \\
\text { microfinance. } \\
\text { 3.8 Achieve universal health coverage, including } \\
\text { financial risk protection, access to quality } \\
\text { essential health-care services and access to safe, } \\
\text { effective, quality, and affordable essential } \\
\text { medicines and vaccines for all. } \\
\text { 8.2; 8.3 Promote development-oriented policies } \\
\text { that support productive activities, decent job } \\
\text { creation, entrepreneurship, creativity, and } \\
\text { innovation, and encourage the formalization and } \\
\text { growth of micro-, small-, and medium-sized } \\
\text { enterprises, including through access to financial } \\
\text { services. 8.5 By 2030, achieve full and productive } \\
\text { employment and decent work for all women and } \\
\text { men, including for young people and persons } \\
\text { with disabilities, and equal pay for work of equal } \\
\text { value. }\end{array}$ \\
\hline
\end{tabular}

\begin{tabular}{cc} 
ECN5 & $\begin{array}{c}204-1 \\
\text { spending on local } \\
\text { suppliers }\end{array}$ \\
\hline
\end{tabular}

8.3
COBIT 2019 (Governance and Management Objectives)

1.2; 1.4 By 2030, ensure that all men and women, in particular the poor and the vulnerable, have equal rights to economic resources, as well as cess to basic services, ownership, and control over land and other forms of property heritance, natural resources, appropriate new microfinance. financial risk protection, access to quality sential health-care services and access to safe, medicines and vaccines for all.

8.2; 8.3 Promote development-oriented policies that support productive activities, decent job creation, entrepreneurship, creativity, and innovation, and encourage the formalization and enterprises, including through access to financial services. 8.5 By 2030, achieve full and productive men, including for young people and persons value.
APO04.03 Monitor and scan the technology environment; APO04.06 Monitor the implementation and use of innovation;

APO12.05 Define a risk management action portfolio;

DSS04.02 Maintain business resilience.

\section{APO05.02 Evaluate and select programs to fund; APO07.06 Manage contract staff.}

1.1 By 2030, eradicate extreme poverty for all people everywhere, currently measured as people living on less than USD 1.25 a day. $\mathbf{1 . 3}$ Implement nationally appropriate social protection systems and measures for all, including floors, and by 2030 achieve substantial coverage of the poor and the vulnerable.

10.4 Adopt policies, especially fiscal, wage, and social protection policies, and progressively achieve greater equality.

17.1 Strengthen domestic resource mobilization, including through international support to developing countries, to improve domestic capacity for tax and other revenue collection. 17.3 Mobilize additional financial resources for developing countries from multiple sources.
EDM05.02 Direct stakeholder engagement, communication and reporting.
8.4 Improve, progressively, through 2030, global resource efficiency in consumption and production and endeavor to decouple economic growth from environmental degradation, in accordance with the 10-year framework of programs on sustainable consumption and production, with developed countries taking the lead.

12.2 By 2030, achieve the sustainable management and efficient use of natural resources. 12.5 By 2030, substantially reduce waste generation through prevention, reduction,
BAI09.03 Manage the asset life cycle. products and their recycling, and reuse. 
Table 1. Cont.

\begin{tabular}{|c|c|c|c|}
\hline $\begin{array}{l}\text { Dimension } \\
\text { Indicator }\end{array}$ & $\begin{array}{l}\text { Global Reporting } \\
\text { Initiative (GSSB) }\end{array}$ & $\begin{array}{l}\text { Sustainable Development Goals } \\
\text { (Targets Associated) }\end{array}$ & $\begin{array}{l}\text { COBIT } 2019 \text { (Governance and } \\
\text { Management Objectives) }\end{array}$ \\
\hline EVR2 & $\begin{array}{c}302-1=>\text { Energy } \\
\text { consumption within the } \\
\text { organization }\end{array}$ & 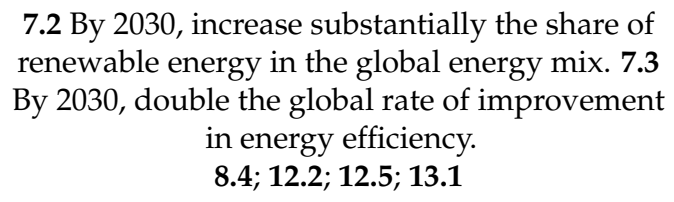 & $\begin{array}{l}\text { BAI04.01 Assess current availability, } \\
\text { performance and capacity and create } \\
\text { a baseline. }\end{array}$ \\
\hline EVR3 & 302-3 => Energy intensity & $7.3 ; 8.4 ; 12.2 ; 13.1$ & $\begin{array}{l}\text { BAI04.02 Assess business impact; } \\
\text { DSS01.05 Manage facilities. }\end{array}$ \\
\hline EVR4 & $\begin{array}{l}302-4=>\text { Reduction of } \\
\text { energy consumption }\end{array}$ & $7.3 ; 8.4 ; 12.2 ; 13.1$ & $\begin{array}{l}\text { BAI04.04 Monitor and review } \\
\text { availability and capacity. }\end{array}$ \\
\hline EVR5 & $\begin{array}{c}302-5=>\text { Reductions in } \\
\text { energy requirements of } \\
\text { products and services }\end{array}$ & $7.3 ; 8.4 ; 12.2 ; 13.1$ & $\begin{array}{l}\text { BAI04.05 Investigate and address } \\
\text { availability, performance and capacity } \\
\text { issues. }\end{array}$ \\
\hline
\end{tabular}

6.3 By 2030, improve water quality by reducing pollution, eliminating dumping, and minimizing release of hazardous chemicals and materials, halving the proportion of untreated wastewater and substantially increasing recycling and safe reuse globally. 6.4 By 2030, substantially increase water-use efficiency across all sectors and ensure sustainable withdrawals and supply of freshwater to address water scarcity and substantially reduce the number of people suffering from water scarcity. 6.A By 2030, expand international cooperation and capacity-building support to developing countries in water- and sanitation-related activities and programs, including water harvesting, desalination, water efficiency, wastewater treatment, recycling, and reuse technologies. 6.B Support and strengthen the participation of local communities in improving water and sanitation management.

12.4 By 2020, achieve the environmentally sound management of chemicals and all wastes throughout their life cycle, in accordance with agreed international frameworks, and significantly reduce their release to air, water, and soil in order to minimize their adverse impacts on human health and the environment.
BAI04.04 Monitor and review availability and capacity.
3.9 By 2030, substantially reduce the number of deaths and illnesses from hazardous chemicals and air, water, and soil pollution and contamination.

$$
12.4 ; 13.1
$$

14.3 Minimize and address the impacts of ocean acidification, including through enhanced scientific cooperation at all levels.

15.2 By 2020, promote the implementation of sustainable management of all types of forests, halt deforestation, restore degraded forests, and substantially increase afforestation and reforestation globally. 
Table 1. Cont.

\begin{tabular}{cccc}
\hline $\begin{array}{c}\text { Dimension } \\
\text { Indicator }\end{array}$ & $\begin{array}{c}\text { Global Reporting } \\
\text { Initiative (GSSB) }\end{array}$ & $\begin{array}{c}\text { Sustainable Development Goals } \\
\text { (Targets Associated) }\end{array}$ & $\begin{array}{c}\text { COBIT 2019 (Governance and } \\
\text { Management Objectives) }\end{array}$ \\
\hline EVR8 & $\begin{array}{c}\text { 305-5 => Reduction of } \\
\text { GHG emissions }\end{array}$ & $\mathbf{1 3 . 1 ; \mathbf { 1 4 . 3 } ; \mathbf { 1 5 . 2 }}$ & DSS01.05 Manage facilities. \\
\hline
\end{tabular}

$\begin{array}{cc}\text { EVR9 } & 306-1=>\text { Waste generation } \\ \text { and significant } \\ \text { waste-related impacts }\end{array}$

$3.9 ; 6.3 ; 6.4 ; 6.6$ By 2020 , protect and restore water-related ecosystems, including mountains, forests, wetlands, rivers, aquifers, and lakes; 12.4;
BAI09.03 Manage the asset life cycle.

$$
\text { 14.1; }
$$

\begin{tabular}{|c|c|c|c|}
\hline EVR10 & $\begin{aligned} 306-5= & >\text { Waste directed to } \\
& \text { disposal }\end{aligned}$ & $\begin{array}{l}\text { 6.6; } 14.2 \text { By 2020, sustainably manage and } \\
\text { protect marine and coastal ecosystems to avoid } \\
\text { significant adverse impacts, including by } \\
\text { strengthening their resilience, and take action for } \\
\text { their restoration in order to achieve healthy and } \\
\text { productive oceans. } \\
\text { 15.1 By 2020, ensure the conservation, } \\
\text { restoration, and sustainable use of terrestrial and } \\
\text { inland freshwater ecosystems and their services, } \\
\text { in particular forests, wetlands, mountains, and } \\
\text { drylands, in line with obligations under } \\
\text { international agreements. } 15.5 \text { Take urgent and } \\
\text { significant action to reduce the degradation of } \\
\text { natural habitats, halt the loss of biodiversity, and, } \\
\text { by 2020, protect and prevent the extinction of } \\
\text { threatened species. }\end{array}$ & BAI09.03 Manage the asset life cycle. \\
\hline EVR11 & $\begin{array}{c}308-1=>\text { New suppliers } \\
\text { that were screened using } \\
\text { environmental criteria }\end{array}$ & & $\begin{array}{l}\text { APO10.03 Manage vendor } \\
\text { relationships and contracts. }\end{array}$ \\
\hline SCL1 & $\begin{array}{c}401-1=>\text { New employee } \\
\text { hires and employee } \\
\text { turnover }\end{array}$ & $\begin{array}{l}\text { 5.1 End all forms of discrimination against all } \\
\text { women and girls everywhere. } \\
\text { 8.5; 10.3 Ensure equal opportunity and reduce } \\
\text { inequalities of outcome, including by } \\
\text { eliminating discriminatory laws, policies, and } \\
\text { practices and promoting appropriate legislation, } \\
\text { policies, and action in this regard. }\end{array}$ & $\begin{array}{l}\text { APO07.01 Acquire and maintain } \\
\text { adequate and appropriate staffing. }\end{array}$ \\
\hline SCL2 & $\begin{array}{l}402-1=>\text { Minimum notice } \\
\text { periods regarding } \\
\text { operational changes }\end{array}$ & $\begin{array}{l}\text { 8.8 Protect labor rights and promote safe and } \\
\text { secure working environments for all workers, } \\
\text { including migrant workers, in particular women } \\
\text { migrants, and those in precarious employment. }\end{array}$ & $\begin{array}{l}\text { APO07.02 Identify key IT personnel; } \\
\text { BAI05.06 Embed new approaches; } \\
\text { BAI06.01 Evaluate, prioritize and } \\
\text { authorize change requests. }\end{array}$ \\
\hline SCL3 & $\begin{array}{l}403-5=>\text { Worker training } \\
\text { on occupational health } \\
\text { and safety }\end{array}$ & 8.8 & DSS01.05 Manage facilities. \\
\hline
\end{tabular}


Table 1. Cont.

\begin{tabular}{|c|c|c|c|}
\hline $\begin{array}{l}\text { Dimensior } \\
\text { Indicator }\end{array}$ & $\begin{array}{l}\text { Global Reporting } \\
\text { Initiative (GSSB) }\end{array}$ & $\begin{array}{l}\text { Sustainable Development Goals } \\
\text { (Targets Associated) }\end{array}$ & $\begin{array}{l}\text { COBIT } 2019 \text { (Governance and } \\
\text { Management Objectives) }\end{array}$ \\
\hline SCL4 & $\begin{array}{c}404-1=>\text { Average hours of } \\
\text { training per year per } \\
\text { employee }\end{array}$ & $\begin{array}{l}\text { 4.3 By 2030, ensure equal access for all women } \\
\text { and men to affordable and quality technical, } \\
\text { vocational, and tertiary education, including } \\
\text { university. 4.4 By 2030, substantially increase the } \\
\text { number of youth and adults who have relevant } \\
\text { skills, including technical and vocational skills, } \\
\text { for employment, decent jobs, and } \\
\text { entrepreneurship. } 4.5 \text { By 2030, eliminate gender } \\
\text { disparities in education and ensure equal access } \\
\text { to all levels of education and vocational training } \\
\text { for the vulnerable, including persons with } \\
\text { disabilities, indigenous peoples, and children in } \\
\text { vulnerable situations. } \\
\text { 5.1; 8.2 Achieve higher levels of economic } \\
\text { productivity through diversification, } \\
\text { technological upgrading, and innovation, } \\
\text { including through a focus on high-value added } \\
\text { and labor-intensive sectors. 8.5 By 2030, achieve } \\
\text { full and productive employment and decent } \\
\text { work for all women and men, including for } \\
\text { young people and persons with disabilities, and } \\
\text { equal pay for work of equal value. 10.3 }\end{array}$ & $\begin{array}{l}\text { APO01.08 Define target skills and } \\
\text { competencies; } \\
\text { APO07.03 Maintain the skills and } \\
\text { competencies of personnel; } \\
\text { DSS04.06 Conduct continuity plan } \\
\text { training. }\end{array}$ \\
\hline
\end{tabular}

404-2 => Programs for

SCL5 upgrading employee skills and transition assistance

programs

404-3 => Percentage of employees receiving

SCL6 regular performance and career development reviews
$8.2 ; 8.5$
APO07.03 Maintain the skills and competencies of personnel.
APO07.04 Assess and recognize/reward employee job performance.
8.7 Take immediate and effective measures to eradicate forced labor, end modern slavery and human trafficking, and secure the prohibition and elimination of the worst forms of child labor, and by 2025, end child labor in all its forms.

16.2 End abuse, exploitation, trafficking, and all forms of violence against and torture of children. including recruitment and use of child soldiers,

APO10.04 Manage vendor risk. suppliers at significant risk for incidents of child labor

409-1 => Operations and suppliers at significant SCL8 risk for incidents of forced or compulsory labor

414- 1 => New suppliers

SCL9 that were screened using social criteria
8.7

APO10.04 Manage vendor risk.

5.2 Eliminate all forms of violence against all women and girls in the public and private spheres, including trafficking and sexual and other types of exploitation. 8.8; 16.1 Significantly reduce all forms of violence and related death rates everywhere.
APO10.03 Manage vendor relationships and contracts.
416-2 => Incidents of noncompliance

SCL10 concerning the health and safety impacts of products and services
APO13.03 Monitor and review the information security management system (ISMS). 
Table 1. Cont.

\begin{tabular}{|c|c|c|c|}
\hline $\begin{array}{l}\text { Dimension } \\
\text { Indicator }\end{array}$ & $\begin{array}{l}\text { Global Reporting } \\
\text { Initiative (GSSB) }\end{array}$ & $\begin{array}{l}\text { Sustainable Development Goals } \\
\text { (Targets Associated) }\end{array}$ & $\begin{array}{l}\text { COBIT } 2019 \text { (Governance and } \\
\text { Management Objectives) }\end{array}$ \\
\hline \multirow[t]{2}{*}{ SCL11 } & \multirow{2}{*}{$\begin{array}{c}417-1=>\text { Requirements for } \\
\text { product and service } \\
\text { information and labeling }\end{array}$} & \multirow[t]{2}{*}{12.8} & $\begin{array}{l}\text { APO14.02 Define and maintain a } \\
\text { consistent business glossary. }\end{array}$ \\
\hline & & & $\begin{array}{l}\text { DSS01.02 Manage outsourced I\&T } \\
\text { services. }\end{array}$ \\
\hline SCL12 & $\begin{array}{l}417-2=>\text { Incidents of } \\
\text { noncompliance } \\
\text { concerning product and } \\
\text { service information and } \\
\text { labeling }\end{array}$ & 16.3 & $\begin{array}{l}\text { DSS01.01 Perform operational } \\
\text { procedures. }\end{array}$ \\
\hline SCL13 & $\begin{array}{c}418-1=>\text { Substantiated } \\
\text { complaints concerning } \\
\text { breaches of customer } \\
\text { privacy and losses of } \\
\text { customer data }\end{array}$ & $16.3 ; 16.10$ & $\begin{array}{l}\text { APO13.01 Establish and maintain an } \\
\text { information security management } \\
\text { system (ISMS). }\end{array}$ \\
\hline SCL14 & $\begin{array}{c}419-1=>\text { Noncompliance } \\
\text { with laws and regulations } \\
\text { in the social and economic } \\
\text { area }\end{array}$ & 16.3 & $\begin{array}{l}\text { MEA03.03 Confirm external } \\
\text { compliance. }\end{array}$ \\
\hline
\end{tabular}

Legend: ECN: economic; EVR: environmental; GVN: governance; SCL: social.

Environmental dimension $=11$ indicators

- The environmental indicators, comprising water consumption, $\mathrm{CO}_{2}$ emissions, energy consumption, use of materials, and products and services, show convergence with seven items in the COBIT structure.

- The relationship with the following objectives was also observed: ODS3-good health and well-being, ODS6 - clean water and sanitation, ODS7-affordable and clean energy, ODS8-decent work and economic growth, ODS12-responsible consumption and production, ODS13 — climate action, ODS14-life below water, and ODS15-life on land.

Economic dimension $=$ six indicators

- The economic indicators prepared by the subsets economic performance, indirect impacts, purchasing practices, and products highlight the similarity of content with 13 COBIT items.

- $\quad$ Regarding the SDGs, it was observed that the economic aspect found convergence in the SDG1-non-poverty, SDG3 - health and well-being, SDG05-gender equality, SDG8 - decent work and economic growth, SDG9-industry, innovation, and infrastructure, ODS10 - reduce inequalities, ODS11—sustainable cities and communities, ODS13 — climate action, and ODS17-partnerships for the goals.

Social dimension $=14$ indicators

- The social indicators, represented by the subset labor practices, training, products, and society, are similar to 17 items of COBIT.

- In relation to the relationship with the SDGs, adherence to the objectives SDG4quality education, SDG5-gender equity, SDG8 - decent work and economic growth, SDG10-reduction of inequality within and between countries, SDG12-responsible consumption and production, and SDG16 - peace, justice, and strong institutions. Governance $=19$ indicators

- The governance indicators represented by the strategy, ethics, and risk analysis subsets have similarities with 31 COBIT items.

- When observing the relationship of these indicators with the SDGs, their adherence to SDG16- peace, justice, and strong institutions was identified. 
As a result of this analysis, among the 50 converging items identified in the comparative checks between COBIT, GRI, and SDGs, there were the governance indicators with 19 items, the social indicators with 14 similar items, followed by the environmental indicators with 11 similar items, and ending with the economic indicators with six items.

Referring to the above finding, there is greater adherence of environmental and social indicators to COBIT requirements, and, at the same time, this confirms the trends of the ESG approach recently adopted by companies, which is supported by the socioenvironmental and governance indicators developed and disclosed by some data analysis companies of risk/investments such as MSCI's Domini Social Index (DSI) and KDL400 Social Index, Morningstar's Sustainalytics, and Bloomberg's ESG which, monthly, release ESG risk assessments from more than 400 companies, including AT\&T (Dallas, TX, USA), Dell (Austin, TX, USA), Facebook (Menlo Park, CA, USA), Google (Mountain View, CA, USA), IBM (Armonk, NY, USA), Microsoft (Redmond, WA, USA), and SAP (Walldorf, Germany).

Considering the possibilities of linking GRI reporting items, SDGs, and COBIT requirements and adopting the premise that GRI standards are adopted by software and IT companies, we sought to analyze whether sustainability in companies can be encouraged by adopting COBIT maturity models aligned with SDGs. As a result of the checklist presented above, it was found that of the 231 COBIT items, 99 belong to the APO and EDM domains, and that items in these domains total 43 of the 64 GRI and SDG indicators listed for this study.

\subsection{Alignment between Corporate Sustainability Goals and SDG, COBIT, and GRI}

Searches were conducted on the corporate websites of the largest global technology companies, such as Amazon (Seattle, WA, USA) [45], AT\&T (Dallas, TX, USA) [46,47], Dell (Round Rock, TX, USA) [48], Equinix (Redwood City, CA, USA) [49], Facebook (Menlo Park, CA, USA) [50], Google (Mountain View, CA, USA) [51,52], IBM (Armonk, NY, USA) [53,54], Microsoft (Redmond, WA, USA) [55], Oracle (Austin, TX, USA) [56-58], PayPal (San Jose, CA, USA) [59], Salesforce (San Francisco, CA, USA) [60], SAP (Walldorf, Germany) [61], and Tata (Mumbai, India) [62] in order to obtain the sustainability data published by these organizations, in order to verify which indicators are used, to identify whether the sustainability indicators presented by these companies in their reports are adherent to the set of indicators developed by this study. The data obtained in the surveys and the comparison of indicators are presented in Table 2.

Among the sustainability reports of the companies above, it was observed that the reports of the companies Amazon (Bellevue, DC, USA), Facebook (Cambridge, MA, USA), and Google (Menlo Park, CA, USA) did not use the GRI standard, and the report of the company Salesforce does not provide the necessary indications to carry out the comparisons, which limited the analyses, making it impossible to include these companies in the process of verifying the use of the SDGs in the composition of sustainability reports and in the corporate strategy of the companies.

It was observed that the surveyed companies established sustainability goals related to climate change, the efficient use of energy and water, in the education of employees and the community, in sustainable innovation, in gender equity, and in good labor relations (See Table 2).

The objectives of sustainable development, defined by the UN in 2015, find in the corporate environment a strong ally, as can be seen in the sustainability reports analyzed in which the following SDGs are the strategic objectives of seven of the nine companies analyzed. The prioritized objectives are: SDG3 (good health and well-being), SDG4 (quality education), SDG5 (gender equality), SDG7 (affordable and clean energy), SDG8 (decent work and economic growth), SDG9 (industries, innovation, and infrastructure), SDG13 (climate action), and SDG17 (partnership for the goals). SDG12 (responsible consumption and production) is part of the strategy of companies that produce electronic devices. 
Table 2. Alignment among corporate sustainability goals and SDG, COBIT, and GRI.

\begin{tabular}{|c|c|c|c|}
\hline CIA & Goals and Objectives & SDGs Prioritized by Companies & $\begin{array}{c}\text { Indicators Prioritized versus } \\
\text { Proposed Indicators }\end{array}$ \\
\hline 岁 & $\begin{array}{l}\text { While we are focused on today's critical } \\
\text { issues, we are maintaining our } \\
\text { commitments to help tackle the ongoing } \\
\text { climate emergency. AT\&T has signed } \\
\text { agreements surpassing } 1.5 \text { gigawatts of } \\
\text { renewable energy capacity, making us } \\
\text { one of the largest corporate purchasers in } \\
\text { the U.S. } \\
\text { To enhance the resiliency of our } \\
\text { operations, our Climate Change Analysis } \\
\text { Tool currently helps visualize } \\
\text { climate-related risks to network } \\
\text { infrastructure and operations in the } \\
\text { southeastern U.S. up to } 30 \text { years into the } \\
\text { future, and we are making the data sets } \\
\text { we use available to external organizations } \\
\text { conducting their own research. }\end{array}$ & $\begin{array}{c}\text { AT\&T purpose, to create } \\
\text { connection-with each other, with what } \\
\text { people need to thrive in everyday lives, } \\
\text { and with the stories and experiences that } \\
\text { matter, is aligned with the UN SDGs. The } \\
\text { SDGs chosen as the focus of AT\&T are: } \\
\text { SDG3 GOOD HEALTH and } \\
\text { WELL-BEING and Target 3.6; SDG4 } \\
\text { QUALITY EDUCATION and Target } 4.4 \text {. } \\
\text { SDG5 GENDER EQUALITY and Target } \\
\text { 5.1, 5.2, and 5.5 and 5.B. } \\
\text { SDG8 DECENT WORK and ECONOMIC } \\
\text { GROWTH and Target 8.4, 8.5, 8.6, 8.8. } \\
\text { SDG9 INDUSTRY, INNOVATION, and } \\
\text { INFRASTRUCTURE with Target 9.1, 9.4. } \\
\text { SDG11 SUSTAINABLE CITIES and } \\
\text { COMMUNITIES with Target 11.3, 11.6. } \\
\text { SDG13 CLIMATE ACTION with Target } \\
\text { 13.1, 13.3. } \\
\text { SDG16 PEACE, JUSTICE and STRONG } \\
\text { INSTITUTIONS with Target 16.2, 16.10, } \\
\text { 16B, and } \\
\text { SDG17 PARTNERSHIP FOR THE } \\
\text { GOALS with Target 17.16 and 17.17 }\end{array}$ & $\begin{array}{l}25 \text { items GRI not found. } \\
30 \text { COBIT requirements not } \\
\text { found. } \\
9 \text { SDGs chosen at company. }\end{array}$ \\
\hline 睤 & $\begin{array}{l}\text { Global Environmental Policy-At Dell } \\
\text { Technologies, we believe that we can be } \\
\text { most successful as a } \\
\text { sustainability-focused company by } \\
\text { putting technology and expertise to work } \\
\text { where they can do the most good for } \\
\text { people and the planet. By setting } \\
\text { science-based targets we are ensuring our } \\
\text { own sustainability, as well as supporting } \\
\text { the needs of businesses in the future. Our } \\
\text { customers need to know we have their } \\
\text { back and can help them reduce energy } \\
\text { use in the long term. It has been an } \\
\text { extremely useful process to go through: } \\
\text { to understand the challenges and the } \\
\text { potential technical solutions, to invest in } \\
\text { the capability to measure progress, and of } \\
\text { course, there are cost savings: if we can } \\
\text { reduce the energy our products use, we } \\
\text { benefit from that. }\end{array}$ & $\begin{array}{l}\text { Considering the content of the Dell } \\
\text { company's sustainability report, synergy } \\
\text { with the following SDGs can be } \\
\text { identified: } \\
\text { SDG1-NO POVERETY; SDG3; SDG4; } \\
\text { SDG5; SDG6-CLEAN WATER AND } \\
\text { SANITATION (A,B); } \\
\text { SDG7-AFFORDABLE AND CLEAN } \\
\text { ENERGY; SDG8; SDG9; SDG10-REDUCE } \\
\text { INEQUALITIES; SDG11; } \\
\text { SDG12-RESPONSIBLE CONSUMPTION } \\
\text { AND PRODUCTION; SDG13; } \\
\text { SDG14-LIFE BELOW WATER; } \\
\text { SDG15-LIFE ON LAND; SDG16; SDG17. }\end{array}$ & $\begin{array}{l}3 \text { items GRI not found. } \\
3 \text { COBIT requirements not } \\
\text { found. } \\
\text { 16 SDGs identified. }\end{array}$ \\
\hline
\end{tabular}


Table 2. Cont.

\begin{tabular}{|c|c|c|c|}
\hline CIA & Goals and Objectives & SDGs Prioritized by Companies & $\begin{array}{l}\text { Indicators Prioritized versus } \\
\text { Proposed Indicators }\end{array}$ \\
\hline 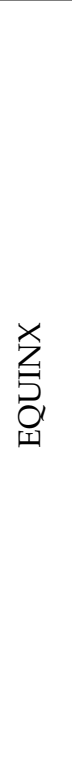 & $\begin{array}{l}\text { To further our \#InServiceTo mindset, we } \\
\text { are committed to protecting, connecting, } \\
\text { and powering a more sustainable digital } \\
\text { world. We are advancing a bold } \\
\text { sustainability agenda and have made } \\
\text { meaningful progress across our } \\
\text { environmental, social and governance } \\
\text { commitments. As a digital leader, we } \\
\text { have the opportunity to harness the } \\
\text { power of technology in order to create a } \\
\text { more sustainable future. At Equinix, we } \\
\text { are committed to protecting the planet, } \\
\text { connecting everyone to the benefits of the } \\
\text { digital world and powering global trust } \\
\text { and responsibility. Our corporate } \\
\text { sustainability program is comprised of } \\
\text { our environment, social and governance } \\
\text { (ESG) initiatives that focus on material } \\
\text { issues to positively impact our key } \\
\text { stakeholders. }\end{array}$ & $\begin{array}{l}\text { Equinix, along with other companies, } \\
\text { countries, and nongovernmental } \\
\text { organizations (NGOs), has chosen to } \\
\text { align our objectives with the United } \\
\text { Nations Sustainable Development Goals } \\
\text { (UN SDGs) in order to accelerate our } \\
\text { collective progress on the world's most } \\
\text { important social and environmental } \\
\text { challenges. While all SDGs are important, } \\
\text { we have prioritized our alignment with } \\
\text { the six SDGs that we believe are the most } \\
\text { material to our business. } \\
\text { SDG5; SDG7; SDG8; SDG9; SDG10; and } \\
\text { SDG13. }\end{array}$ & $\begin{array}{c}18 \text { items GRI not found. } \\
18 \text { COBIT requirements not } \\
\text { found. } \\
\text { 6 SDGs prioritized. }\end{array}$ \\
\hline$\sum_{\oplus}$ & $\begin{array}{l}\text { IBM has a proud history of engagement } \\
\text { with the communities where we operate, } \\
\text { as well as societies globally. We share the } \\
\text { priorities for social advancement that the } \\
17 \text { United Nations Sustainable } \\
\text { Development Goals establish and } \\
\text { endorse the strategy of partnership that } \\
\text { the SDGs call for, because collaboration } \\
\text { has long been IBM's approach to } \\
\text { engaging societal challenges. } \\
\text { IBM's efforts toward these goals can be } \\
\text { seen in our environmental programs, } \\
\text { supply chain practices, corporate social } \\
\text { responsibility work, and our global focus } \\
\text { on diversity and inclusion. We work with } \\
\text { social organizations, governments, and } \\
\text { commercial clients to develop many of } \\
\text { these solutions-some of which you will } \\
\text { find in this report, shown with the SDG } \\
\text { that each initiative can help achieve. }\end{array}$ & $\begin{array}{l}\text { Considering the content of the IBM } \\
\text { company's sustainability report, synergy } \\
\text { with the following SDGs can be } \\
\text { identified: } \\
\text { SDG1; SDG3; SDG4; SDG5; SDG6 (a,b); } \\
\text { SDG7; SDG8; SDG9; SDG10; SDG11; } \\
\text { SDG12; SDG13; SDG14; SDG15; SDG16; } \\
\text { SDG17. }\end{array}$ & $\begin{array}{l}\text { all GRI items found. } \\
\text { all COBIT requirements found. } \\
\text { 16 SDGs identified. }\end{array}$ \\
\hline
\end{tabular}


Table 2. Cont.

\begin{tabular}{|c|c|c|c|}
\hline CIA & Goals and Objectives & SDGs Prioritized by Companies & $\begin{array}{c}\text { Indicators Prioritized versus } \\
\text { Proposed Indicators }\end{array}$ \\
\hline 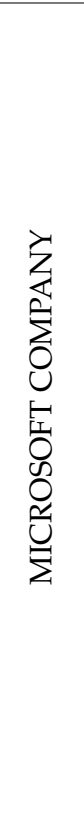 & $\begin{array}{l}\text { Over the past year, we built on this } \\
\text { pledge by announcing a series of } \\
\text { commitments to be water positive by } \\
\text { 2030, zero waste by 2030, and to protect } \\
\text { ecosystems by developing a Planetary } \\
\text { Computer. We grounded our } \\
\text { sustainability strategy and commitments } \\
\text { in the belief that technology can help } \\
\text { solve the world's biggest challenges. } \\
\text { Whenever Microsoft takes on a new and } \\
\text { complex societal issue, we strive first to } \\
\text { learn and then to define a principled } \\
\text { approach to guide our efforts. In 2020, we } \\
\text { did the same with environmental } \\
\text { sustainability. } \\
\text { Definition of focus areas: We focus on } \\
\text { four areas-carbon, water, waste, and } \\
\text { ecosystems- where we can scale, } \\
\text { minimizing the negative impacts of our } \\
\text { operations and maximizing the positive } \\
\text { impacts of our technology. }\end{array}$ & $\begin{array}{l}\text { We are actively engaged in supporting } \\
\text { the UN Sustainable Development Goals } \\
\text { (SDGs) and publicly report how } \\
\text { Microsoft contributes to the global effort } \\
\text { to achieve them. At Microsoft, we have } \\
\text { also reflected on three key pillars that } \\
\text { most of our contributions stand on: } \\
\text { empowering people, strengthening } \\
\text { communities, and protecting the planet. } \\
\text { These pillars correspond most closely to } \\
\text { the following four Global Goals: SDG4, } \\
\text { SDG8, SDG13, and SDG16. For the } \\
\text { Microsoft Devices segment, SGD 3, 5, 6, 7, } \\
\text { 12, 14, and 15 are established, in addition } \\
\text { to the SGD defined as priorities for the } \\
\text { Microsoft Company. }\end{array}$ & $\begin{array}{l}11 \text { items GRI not found. } \\
10 \text { COBIT requirement not } \\
\text { found. } \\
\text { 4 SDGs prioritized. }\end{array}$ \\
\hline 崫 & $\begin{array}{l}\text { Oracle recognizes that sustainability is } \\
\text { good business. That is why we are } \\
\text { committed to developing practices and } \\
\text { products that enable our customers } \\
\text { around the world to put the planet first. } \\
\text { Operations-Sustainability is at the heart } \\
\text { of our business operations-from } \\
\text { managing our use of natural resources to } \\
\text { ensuring responsible supply chain } \\
\text { practices and running sustainable events } \\
\text { globally. } \\
\text { Oracle leads the way in designing } \\
\text { sustainable world-class events for } \\
\text { customers, partners, developers, and } \\
\text { employees. Oracle is also a founding } \\
\text { signatory to the Principles for Sustainable } \\
\text { Events. } \\
\text { Oracle OpenWorld-our largest annual } \\
\text { customer technology } \\
\text { conference-follows a process based on } \\
\text { ISO 20121:2012 event sustainability } \\
\text { management systems. Oracle creates } \\
\text { event sustainability action plans that } \\
\text { prioritize the four event sustainability } \\
\text { goals: WASTE NOT (promote zero } \\
\text { waste); BE COOLER (Model carbon } \\
\text { reduction and responsibility for } \\
\text { corporate events); GIVE BACK (Catalyze } \\
\text { legacies to benefit host destinations) and } \\
\text { HAVE FUN (Inspire attendees through } \\
\text { engaging sustainability experiences). }\end{array}$ & $\begin{array}{l}\text { We all share one planet and are one } \\
\text { humanity. It is a truth both simple and } \\
\text { profound, and one that drives our } \\
\text { sustainability efforts at Oracle. } \\
\text { Sustainability is inherent in the way we } \\
\text { think about and approach nearly every } \\
\text { aspect of our business, from operational } \\
\text { efficiency to product development to } \\
\text { employee engagement. There is always } \\
\text { more work to be completed, and Oracle } \\
\text { remains committed to building a resilient } \\
\text { future for our planet, for humanity, and } \\
\text { for future generations. Together we are } \\
\text { changing lives around the world, and } \\
\text { with the growth in new disruptive } \\
\text { technologies, including the cloud, I am } \\
\text { more hopeful now than ever before that } \\
\text { we can achieve the Sustainable } \\
\text { Development Goals necessary to benefit } \\
\text { our planet and the life it } \\
\text { sustains-SDG2-ZERO HUNGRE; SDG3; } \\
\text { SDG4; SDG8; SDG13; SDG17. }\end{array}$ & $\begin{array}{l}13 \text { items GRI not found. } \\
13 \text { COBIT requirement not } \\
\text { found. }\end{array}$ \\
\hline
\end{tabular}


Table 2. Cont

\begin{tabular}{|c|c|c|c|}
\hline CIA & Goals and Objectives & SDGs Prioritized by Companies & $\begin{array}{c}\text { Indicators Prioritized versus } \\
\text { Proposed Indicators }\end{array}$ \\
\hline 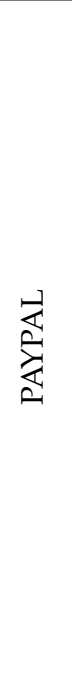 & $\begin{array}{l}\text { In } 2019 \text {, we prioritized initiatives aligned } \\
\text { with our mission and values and worked } \\
\text { to integrate key ESG factors into the very } \\
\text { fabric of our business. Throughout the } \\
\text { year, we introduced new wellness and } \\
\text { engagement programs for our employees, } \\
\text { advanced our cross-sector social impact } \\
\text { partnership strategy, expanded our } \\
\text { capabilities to support charitable giving, } \\
\text { advanced our thought leadership on } \\
\text { financial health, and made further } \\
\text { commitments to our communities and } \\
\text { our planet. } \\
\text { As part of our ESG materiality } \\
\text { assessment, we also examined how our } \\
\text { business activities and key priority areas } \\
\text { align with the United Nations' } \\
\text { Sustainable Development Goals (SDGs). }\end{array}$ & $\begin{array}{l}\text { Overall, PayPal makes a direct, positive } \\
\text { contribution to } 10 \text { of the } 17 \text { SDGs, with } \\
\text { the greatest influence on the five goals } \\
\text { listed below. Meanwhile, we remain } \\
\text { focused on responsibly managing our } \\
\text { operations and supporting our } \\
\text { communities consistent with all of the } \\
\text { Global Goals. } \\
\text { SDG1 (Target 1.4); SDG8 (Target } 8.5 \text { ); } \\
\text { SDG9 (Target 9.3); SDG10 (Target 10.C); } \\
\text { SDG17 (Target 17.17). } \\
\text { SDG4; SDG5; SDG3; SDG16; SDG6; } \\
\text { SDG7, the company makes the statement } \\
\text { in the report, but does not set clear } \\
\text { objectives. }\end{array}$ & $\begin{array}{l}35 \text { items GRI not found. } \\
45 \text { COBIT requirement not } \\
\text { found. }\end{array}$ \\
\hline 密 & $\begin{array}{l}\text { At SAP, our purpose is to "help the world } \\
\text { run better and improve people's lives" by } \\
\text { empowering our customers to create a } \\
\text { better economy, society, and environment } \\
\text { for the world. In line with our purpose, } \\
\text { we are committed to supporting the } \\
\text { United Nations Sustainable Development } \\
\text { Goals (UN SDGs). Technology-driven } \\
\text { innovation underpins how SAP, together } \\
\text { with our customers and our partner } \\
\text { ecosystem, can execute initiatives across } \\
\text { all } 17 \text { of the UN SDGs. Our goal is to lead } \\
\text { the evolution of technology while also } \\
\text { helping ensure that the focus remains on } \\
\text { taking responsibility for its outcomes and } \\
\text { societal effects. Examples of how we are } \\
\text { carrying this out include the focus of } \\
\text { social investments on building digital } \\
\text { skills and our guiding principles for } \\
\text { artificial intelligence and governance. }\end{array}$ & $\begin{array}{l}\text { In assessing our impact on society } \\
\text { through the SAP portfolio, our } \\
\text { stakeholders identified seven SDGs as } \\
\text { material: } \\
\text { SDG9; SDG3; SDG8; SDG13; SDG17; } \\
\text { SDG12; SDG4. }\end{array}$ & $\begin{array}{l}27 \text { items GRI not found. } \\
36 \text { COBIT requirement not } \\
\text { found. } \\
6 \text { SDG prioritized. }\end{array}$ \\
\hline
\end{tabular}


Table 2. Cont.

\begin{tabular}{|c|c|c|c|}
\hline CIA & Goals and Objectives & SDGs Prioritized by Companies & $\begin{array}{l}\text { Indicators Prioritized versus } \\
\text { Proposed Indicators }\end{array}$ \\
\hline 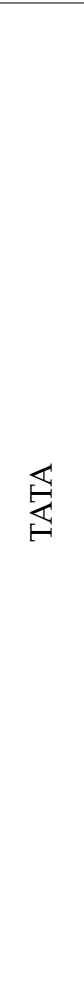 & $\begin{array}{l}\text { TCS publishes the Sustainability Report } \\
\text { on an annual basis. The last report was } \\
\text { published for FY 2018. The current report, } \\
\text { for FY } 2019 \text { (year ending } 31 \text { March 2019), } \\
\text { is the 13th such report published by TCS } \\
\text { till date. This report has been prepared in } \\
\text { accordance with the GRI Standards: Core } \\
\text { option. Our responsible sourcing } \\
\text { program motivates our suppliers to } \\
\text { adhere to } 100 \% \text { regulatory compliances } \\
\text { and strive for better sustainability } \\
\text { performance. Our Sustainable Supply } \\
\text { Chain policy and Green Procurement } \\
\text { policy outline our commitment to make } \\
\text { our supply chain more responsible and } \\
\text { sustainable. } \\
\text { TCS' focus on resource use and waste } \\
\text { reduction has led to the reduction of the } \\
\text { consumption of the per capita paper } \\
\text { consumption by } 12.6 \% \text { over the previous } \\
\text { year and } 87 \% \text { over the baseline FY } 2008 \text {. } \\
\text { The success of this drive can be attributed } \\
\text { to the awareness created among } \\
\text { employees and the enforcement of } \\
\text { printing discipline through automated } \\
\text { and manual means. }\end{array}$ & $\begin{array}{l}\text { Analyzing the sustainability report of } \\
\text { TATA Consultancy Services (TCS), it was } \\
\text { identified that the following SDGs are } \\
\text { identified as the Company's priority, } \\
\text { namely: SDG1, SDG3; SDG4; SDG5; } \\
\text { SDG6; SDG7; SDG8; SDG9; SDG11; } \\
\text { SDG12; SDG13; SDG14. }\end{array}$ & $\begin{array}{l}31 \text { items GRI not found. } \\
39 \text { COBIT requirement not } \\
\text { found. } \\
12 \text { ODS prioritized. }\end{array}$ \\
\hline
\end{tabular}

\subsection{Proposed Indicators}

Based on the analysis performed on the previous sections, including the identification of the sustainability indicators proposed by the GRI, SDG, and COBIT and the mapping of the sustainability goals adopted by the main IT companies aligned with GRI, SDG, and COBIT, 50 sustainability indicators were identified to be adopted by micro and small software companies. These indicators comprise the three dimensions: environmental, social, and economic, in addition to governance.

4.4. Relationship between the Sustainable Indicators in the Reviewed Reports and the One Proposed This Study

In order to evaluate the set of indicators proposed by this study, the indications of the GRI reporting items were verified, as well as the SDG indications that the companies linked to their sustainable goals, aiming to identify whether the proposed indicators are supported in the sustainability reports published by the analyzed companies. These indications are noted in the report and in indexes referenced in the reports, whenever the document uses the standard established by the GRI.

It is noteworthy that the analyses of the sustainability reports suggest that the essential report model has an average of 19 indicators adhering to the proposed model. The comprehensive model, on the other hand, has 41 of the 50 proposed indicators adhered to.

Among the proposed indicators and those reported in the analyzed essential sustainability reports, it was observed that the items related to governance have the lowest adherence, given that of the 19 proposed indicators, nine were not reported by the companies that use these standards, especially for the indicators that address governance actions aimed at sustainability.

As for the indicators related to the environmental, economic, and social dimensions, it was observed that of the six economic indicators proposed, on average, 3.75 are not included in the analyzed essential model reports. In the environmental dimension of the 
11 proposed indicators, on average, six were not reported in the analyzed reports, and in the social dimension of the 14 proposed indicators, on average, 10 are not included in the analyzed reports.

At the same time, the reports that use the comprehensive model showed greater adherence to the proposed indicators, highlighting the governance indicators with $84.21 \%$ and environmental indicators with $83.64 \%$ of adherence. The social and economic indicators showed $77.14 \%$ and $80 \%$ adherence, respectively, to the set of indicators proposed by this study.

When considering the three dimensions of sustainability—environmental, economic, and social, the analyzed reports suggest that companies focus their efforts on environmental and social indicators, confirming the findings of this research that found a greater relationship between these indicators and the requirements of the COBIT maturity model. These findings are also supported by the SDG's prioritization related to social and environmental issues reported in the verified reports.

On the other hand, considering that the set of 50 indicators proposed aims to place micro and small companies in the context of sustainability, some indicators prioritized by large companies, if adopted by micro and small companies, can lead them along the paths of sustainability. Among the governance indicators, we highlight risk management and stakeholder engagement. As for the economic aspect, the indicators are of investments in infrastructure and economic impacts and value creation. With regard to the environmental dimension, indicators of efficient use of energy, rational use of water, packaging recycling, and waste disposal lead companies towards sustainability. In the same way, social indicators related to labor relations, engagement with the community, and adoption of inclusion and diversity policies will allow these companies to align themselves with the social and environmental demands required in the global corporate scenario.

\section{Discussion}

The use of indicators to manage the sustainability goals established by companies and to establish sustainable standards of device production in the development of applications/software, suggested by Sage (1997) and Debreceny and Gray (2013), were identified in the analyzed reports.

Considering the SDGs and GRI reporting items, an analysis was carried out to identify their relationship with the requirements of the COBIT model, with the aim of generating a set of indicators that aggregate the three lines of corporate sustainability: environmental, economic, and social.

The result of these analyses is that the environmental and social indicators (GRI and ODS) are more adherent to the COBIT model, reinforcing the current trend of social and environmental indicators $[27,28]$. It was also observed that the economic indicators were less mentioned in the sustainability reports prepared and made available by the companies.

On the other hand, IT corporate governance, which permeates the sustainability aspects considered in this study, presented 19 converging items, reinforcing compliance with international rules linked to Sarbanes-Oxley's transparency and compliance practices, as well as the definitions of the management and strategic alignment established by the GTI and adoption of the COBIT model itself, which is an efficient tool for managing activities carried out in software and information and communication technology companies.

Regarding the set of 50 proposed indicators, it was observed that they are unevenly distributed between environmental, economic, and social aspects, as described below.

- Environmental aspect $\rightarrow$ this dimension linked to the GRI items related to energy presented four items for energy, one item for manager environmental, and three items for products and services, adding up to eight COBIT requirements.

- Economic aspect $\rightarrow$ this dimension has seven items related to the economic and product aspects. One item of policies, two items of corporate environment management, one item of financial management, two items of contract management, and one of data management were verified, totaling seven COBIT requirements. 
- Social aspect $\rightarrow$ Five items of the GRI social—labor relations and one item of socialsociety are strongly similar to eight requirements of COBIT, as shown in Table 1 of this study.

It was also observed that 29 items of governance, strategy, and engagement of stakeholders established in the GRI are following 16 requirements of the EDM dimension of COBIT, and that these comprise the analysis of the ESG indicators of the rating companies. In view of the results, it was confirmed that the proposed indicators include the three aspects of sustainability-environmental, economic, and social.

Regarding the feasibility of using the proposed set of indicators, although limited, given the number of sustainability reports analyzed, these were adequate to the current concerns of technology companies with the use of renewable energy, and sustainable productive means, considering the entire product and/or service life cycle and greenhouse gas emissions from its operations and suppliers.

At the same time, it is observed that investors have been looking for companies that have their strategy focused on the sustainability of their operations, especially those that aim to preserve and optimize the use of natural resources, control greenhouse gas emissions, and manage waste generated, as well as adopting inclusive policies in the hiring of its employees, engaging partners, suppliers, and local communities in business, and within its area of operation, generating value for society.

In this new scenario of opportunities, micro and small companies can and should take ownership of sustainable practices aiming to improve their operational performance, due to the satisfaction and engagement of their employees and partners, at the same time obtaining investments to expand their business and expand the portfolio of customers, generating value for partners, employees, and the parties involved.

\section{Conclusions}

This study showed the relationship between the GRI report items and the SDG sustainability indicators and requirements of the COBIT maturity model and presented, as a result of these relationships, a set of 50 indicators of similar content. The result of this comparative analysis was the identification of 26 items from COBIT, 21 items from GRI reports, 16 objectives, and 48 goals from the SDG that make up the standard essential model. In the case of the comprehensive model reports analyzed, 55 COBIT items, 41 GRI indicators, 16 objectives, and 48 SDG targets were observed when compared with the proposed set of 50 indicators.

This set was put to the test when compared to sustainability reports published by nine multinational technology companies, in which it was identified that these companies focus their efforts on indicators related to governance practices, stakeholder engagement, risk analysis and financial opportunities, investments in infrastructure, targeting for value generation, efficient use of resources such as water and energy, reduction of greenhouse gas emissions, creation of a safe, collaborative, and inclusive work environment, training of workers, management of suppliers with regard to labor relations, and sustainability. It was also identified that these companies established in their corporate goals to meet some ODS, among which stand out the ODS8 (decent work and economic growth) indicated by all companies, the ODS13 (climate action) which is the focus of eight out of nine, and ODS3 (good health and well-being) and ODS9 (industries, innovation, and infrastructure) prioritized by seven of the nine companies analyzed.

Finally, due to the limitations presented in this study, we suggest an expansion of this research, covering a larger number of companies, in order to analyze the economic, social, and environmental aspects of operations in software companies. It is also suggested to conduct research, including micro and small companies, using other methods, such as the application of electronic questionnaires and/or online interviews.

Author Contributions: Conceptualization, M.C.M.; methodology, M.C.M.; software, M.C.M.; validation, M.C.M. and T.C.M.B.C.; formal analysis, M.C.M.; investigation, M.C.M.; resources, M.C.M.; 
data curation, M.C.M.; writing-original draft preparation, M.C.M.; writing—review and editing, M.C.M.; visualization, M.C.M.; supervision, T.C.M.B.C.; project administration, M.C.M. All authors have read and agreed to the published version of the manuscript.

Funding: This research received no external funding.

Institutional Review Board Statement: Not Applicable.

Informed Consent Statement: Not Applicable.

Data Availability Statement: Not Applicable.

Conflicts of Interest: The authors declare no conflict of interest.

\section{References}

1. Niebel, T. ICT and economic growth-Comparing developing, emerging and developed countries. World Dev. 2018, 104, 197-211. [CrossRef]

2. Nirino, N.; Santoro, G.; Miglietta, N.; Quaglia, R. Corporate controversies and company's financial performance: Exploring the moderating role of ESG practices. Technol. Forecast. Soc. Chang. 2021, 162, 120341. [CrossRef]

3. Lee, K.H.; Cin, B.C.; Lee, E.Y. Environmental Responsibility and Firm Performance: The Application of an Environmental, Social and Governance Model. Bus. Strateg. Environ. 2016, 25, 40-53. [CrossRef]

4. Sérgio, E.; Pace, U.; Alessandro, M. Indicadores de Desempenho como Direcionadores de Valor. RAC $2003,7,37-65$.

5. da Veiga, J.E. Indicadores de sustentabilidade. Estud. Avançados 2010, 24, 39-52. [CrossRef]

6. United Nations. Tranforming Our World: The 2030 Agenda for Sustainable Development; United Nations: New York, NY, USA, 2015; Volume 16301.

7. Bharathi, R.; Selvarani, R. A framework for the estimation of OO software reliability using design complexity metrics. In Proceedings of the 2015 International Conference on Trends in Automation, Communications and Computing Technology (I-TACT-15), Bangalore, India, 21-22 December 2015; pp. 1-7.

8. Sage, A.P. Systematic measurements: At the interface between information and systems management, systems engineering, and operations research. Ann. Oper. Res. 1997, 71, 17-35. [CrossRef]

9. Lami, G.; Fabbrini, F.; Buglione, L. An ISO/IEC 33000-Compliant Measurement Framework for Software Process Sustainability Assessment. In Proceedings of the 2014 Joint Conference of the International Workshop on Software Measurement and the International Conference on Software Process and Product Measurement, Rotterdam, The Netherlands, 6-8 October 2014; pp. 50-59.

10. Debreceny, R.S.; Gray, G.L. IT Governance and Process Maturity: A Multinational Field Study. J. Inf. Syst. 2013, 27, 157-188. [CrossRef]

11. Pflieger, J.; Fischer, M.; Kupfer, T.; Eyerer, P. The contribution of life cycle assessment to global sustainability reporting of organizations. Manag. Environ. Qual. 2005, 16, 167-179. [CrossRef]

12. Husted, B.W.; de Sousa-Filho, J.M. Board structure and environmental, social, and governance disclosure in Latin America. J. Bus. Res. 2019, 102, 220-227. [CrossRef]

13. Global Reporting Initiative Gri 101: Foundation 2016 101. GRI Stand. 2018, GRI101, 29.

14. Martinez-Conesa, I.; Soto-Acosta, P.; Palacios-Manzano, M. Corporate social responsibility and its effect on innovation and firm performance: An empirical research in SMEs. J. Clean. Prod. 2017, 142, 2374-2383. [CrossRef]

15. ABES Software. Mercado Brasileiro de Software; ABES Software: São Paulo, Brasil, 2019.

16. Yin, R.K.; Trorell, A.N.A. Estudo de Caso: Planejamento e Metodos, 2nd ed.; Bookman: Porto Alegre, RS, USA, 2001 ; ISBN 8573078529.

17. García-Mireles, G.A.; Moraga, M.Á.; García, F.; Calero, C.; Piattini, M. Interactions between environmental sustainability goals and software product quality: A mapping study. Inf. Softw. Technol. 2018, 95, 108-129. [CrossRef]

18. Hsieh, H.F.; Shannon, S.E. Three approaches to qualitative content analysis. Qual. Health Res. 2005, 15, 1277-1288. [CrossRef] [PubMed]

19. Hák, T.; Janoušková, S.; Moldan, B. Sustainable Development Goals: A need for relevant indicators. Ecol. Indic. 2016, 60, 565-573. [CrossRef]

20. Kibira, D.; Morris, K.K.C.; Kumaraguru, S. Methods and Tools for Performance Assurance of Smart Manufacturing Systems. J. Res. Natl. Inst. Stand. Technol. 2016, 121, 287. [CrossRef]

21. Neugebauer, S.; Martinez-Blanco, J.; Scheumann, R.; Finkbeiner, M. Enhancing the practical implementation of life cycle sustainability assessment-Proposal of a Tiered approach. J. Clean. Prod. 2015, 102, 165-176. [CrossRef]

22. Zalatar, W.F.; Clark, E.E. Development of a Quadruple Bottom Line-based Composite Sustainability Index to Measure Sustainable Performance. IEEE Int. Conf. Ind. Eng. Eng. Manag. 2019, 258-262. [CrossRef]

23. Daim, T.; Justice, J.; Krampits, M.; Letts, M.; Subramanian, G.; Thirumalai, M. Data center metrics: An energy efficiency model for information technology managers. Manag. Environ. Qual. 2009, 20, 712-731. [CrossRef] 
24. Johann, T.; Dick, M.; Kern, E.; Naumann, S. Sustainable development, sustainable software, and sustainable software engineering: An integrated approach. In Proceedings of the 2011 International Symposium on Humanities, Science and Engineering Research, Kuala Lumpur, Malaysia, 6-7 June 2011; pp. 34-39.

25. Hankel, A.; Heimeriks, G.; Lago, P. A Systematic Literature Review of the Factors of Influence on the Environmental Impact of ICT. Technologies 2018, 6, 85. [CrossRef]

26. Global Sustainability Standards Board. Consolidated Set of GRI Sustainability Reporting Standards 2020; Global Sustainability Standards Board: Amsterdam, The Netherlands, 2018.

27. Cort, T.; Esty, D. ESG Standards: Looming Challenges and Pathways Forward. Organ. Environ. 2020, 33, 491-510. [CrossRef]

28. Ortas, E.; Álvarez, I.; Garayar, A. The environmental, social, governance, and financial performance effects on companies that adopt the United Nations Global Compact. Sustainability 2015, 7, 1932-1956. [CrossRef]

29. Gomez-Echeverri, L. Climate and development: Enhancing impact through stronger linkages in the implementation of the Paris Agreement and the Sustainable Development Goals (SDGs). Philos. Trans. A Math. Phys. Eng. Sci. 2018, 376, 20160444. [CrossRef]

30. Johnston, R.B. Transforming Our World: The 2030 Agenda for Sustainable Development; United Nation: New York, NY, USA, 2016.

31. Horn, P.; Grugel, J. The SDGs in middle-income countries: Setting or serving domestic development agendas? Evidence from Ecuador. World Dev. 2018, 109, 73-84. [CrossRef]

32. Bounagui, Y.; Mezrioui, A.; Hafiddi, H. Toward a unified framework for Cloud Computing governance: An approach for evaluating and integrating IT management and governance models. Comput. Stand. Interfaces 2019, 62, 98-118. [CrossRef]

33. Machado, M.C.; Hourneaux Junior, F.; Sobral, F.A. Sustainability in Information Technology: An Analysis of the Aspects Considered in the Model Cobit. J. Inf. Syst. Technol. Manag. 2017, 14, 88-110. [CrossRef]

34. Joshi, A.; Bollen, L.; Hassink, H.; De Haes, S.; Van Grembergen, W. Information \& Management Explaining IT governance disclosure through the constructs of IT governance maturity and IT strategic role. Inf. Manag. 2018, 55, 368-380. [CrossRef]

35. ISACA. COBIT ${ }^{\circledR} 2019$ Framework: Introduction $\mathcal{E}$ Methodology; ISACA: Schaumburg, IL, USA, 2019; ISBN 978-1-60420-763-7.

36. ISACA. COBIT 2019-Governance and Management Objectives; ISACA: Schaumburg, IL, USA, 2019; ISBN 9781604207644.

37. Levstek, A.; Hovelja, T.; Pucihar, A. IT Governance Mechanisms and Contingency Factors: Towards an Adaptive IT Governance Model. Organizacija 2018, 51, 286-310. [CrossRef]

38. Goh, C.F.; Rasli, A.; Khan, S. Corporate governance: A literature review with a focus on the technology firms. Procedia Soc. Behav. Sci. 2014, 129, 39-45. [CrossRef]

39. Aras, G.; Crowther, D. Governance and sustainability: An investigation into the relationship between corporate governance and corporate sustainability. Manag. Decis. 2008, 46, 433-448. [CrossRef]

40. Estevez, E.; Lopes, N.; Janowski, T. Smarte Sustainable Cities: Reconnaissance Study; Shibuya-Ku: Tokyo, Japan, 2016.

41. Ali, S.; Green, P.; Robb, A. Information technology investment governance: What is it and does it matter? Int. J. Account. Inf. Syst. 2015, 18, 1-25. [CrossRef]

42. Van Grembergen, W.; De Haes, S. Measuring and Improving IT Governance. Inf. Syst. Control J. 2005, 2, 34-42.

43. Dao, V.; Langella, I.; Carbo, J. From green to sustainability: Information Technology and an integrated sustainability framework. J. Strateg. Inf. Syst. 2011, 20, 63-79. [CrossRef]

44. Patón-Romero, J.D.; Baldassarre, M.T.; Rodríguez, M.; Runeson, P.; Höst, M.; Piattini, M. Governance and Management of Green IT: A Multi-Case Study. Inf. Softw. Technol. 2021, 129. [CrossRef]

45. Amazon. Proxy Statement 2019 Global Impact Highlights; Amazon: Seattle, DC, USA, 2020.

46. AT\&T. ATET ESG Index; AT\&T: Dallas, TX, USA, 2020.

47. AT\&T. ATET Index: U.N. Sustainable Development Goals; AT\&T: Dallas, TX, USA, 2020.

48. Dell Technologies Inc. DELL Technologies_GRI Standards Content Index; Dell Technologies Inc.: Round Rock, TX, USA, 2020.

49. Equinix, I. Equinix —Sustainability Report; Equinix: Redwood City, CA, USA, 2019.

50. Facebook. FACEBOOK Sustainability Report; Facebook: Menlo Park, CA, USA, 2019.

51. Google. European Union NFRD Report; Google: Mountain View, CA, USA, 2020.

52. Google. Responsible Supply Chain Report 2019; Google: Mountain View, CA, USA, 2019.

53. IBM. IBM and Good Tech: Modeling Responsible Stewardship in the Digital Age; IBM: New York, NY, USA, 2019.

54. IBM. IBM and the U. N. Sustainable Development Goals; IBM: Armonk, NY, USA, 2020.

55. Microsoft Corporate. Reimagining a Better Future Together-Corporate Social Responsability Report; Microsoft Corporate: Redmond, WA, USA, 2020.

56. Oracle. 2019 Corporate Citizenship Report; Oracle: Redwood City, CA, USA, 2019.

57. Oracle. GRI Index — Corporate Citizenship Report; Oracle: Redwood City, CA, USA, 2019.

58. Oracle. GRI Index Material—Corporate Citizenship Report; Oracle: Redwood City, CA, USA, 2019.

59. Paypal. 2019 Global Impact Report; Paypal: San Jose, CA, USA, 2019.

60. Salesforce Inc. FY19 Stakeholder Impact Report; Salesforce Inc.: San Francisco, CA, USA, 2020. 
61. SAP. 2019 SAP Integrated Report; SAP: Walldorf, Germany, 2019.

62. TATA Consultancy Service. Corporate Sustainability Report; TATA Consultancy Service: Mumbai, India, 2019. 